\title{
Pengembangan Sistem Pengontrol Greenhouse melalui Web dengan Interaksi Jejaring Media Sosial Facebook
}

\author{
Oktaf Brillian Kharisma \\ Teknik elektro Fakultas Sains dan Teknologi,UIN Sultan Syarif Kasim Riau \\ e-mail: brilliankharisma@gmail.com
}

\begin{abstract}
Abstrak - Perkembangan teknologi menyebabkan adanya keterkaitan antara teknologi yang satu dengan lainnya, seperti teknologi informasi dan teknologi kendali yang berbasis web melalui jaringan internet. Bahkan dibidang pertanian khususnya dalam pengontrol greenhouse, teknologi masih sangat dibutuhkan. Karena selama ini pengolahan tanaman dalam greenhouse mulai dari pemantauan dan pengendalian masih dilakukan secara manual.

Salah satu solusi yang ditawarkan dalam penelitian adalah dengan membuat sebuah sistem pengontrol greenhouse melalui web yang meliputi pengaturan suhu dan kelembaban, pengaturan intensitas cahaya dan menentukan waktu penyiraman yang semua dapat di kendalikan dan dipantau melalui web dengan jaringan internet secara real time ataupun terjadwal yang kemudian hasilnya dapat juga di pantau melalui media sosial facebook.

Hasil pengujian menunjukkan bahwa sistem telah bekerja dengan baik untuk proses penyiraman dan pemantauan melalui aplikasi web yang telah dibuat. Sedangkan dalam proses post data ke facebook juga $100 \%$ berhasil. Hal ini bergantung pada koneksi jaringan internet.
\end{abstract}

Kata Kunci: kontrol, greenhouse, web server, facebook API, sensor.

\section{Pendahuluan}

Pertumbuhan teknologi informasi khususnya jaringan internet yang semakin pesat, diikuti bertumbuhnya pula aplikasi-aplikasi web seperti halnya aplikasi jejaring media sosial seperti facebook dan twitter yang memudahkan manusia untuk dapat saling bertukar informasi. Sehingga menjadikan jarak bukan lagi menjadi hambatan untuk melakukan aktivitas. Perkembangan teknologi ini telah menyebabkan adanya keterkaitan antara teknologi satu dengan yang lainya, misalnya teknologi informasi dengan teknologi kendali.

Disisi lain, pengolahan greenhouse saat ini masih dilakukan secara manual dan semi otomatis yang berarti bahwa masih membutuhkan campur tangan manusia dalam pengelolaannya. Proses pengolahan manual seperti ini petani diharuskan meninjau secara langsung tanaman didalam greenhouse. Hal ini yang menyebabkan kurang efektifnya sumber daya, lambatnya proses produksi dan biaya pengolahan yang tinggi.

Banyak faktor-faktor yang mempengaruhi di dalam pengolahan tanaman di sektor pertanian dalam greenhouse, misalnya faktor suhu, kelembaban, kebutuhan akan penyinaran atau intensitas cahaya yang digunakan, dan lain-lain. Salah satu faktor yang mempengaruhi pada perkembangan tanaman yaitu penyiraman. Penyiraman merupakan suatu hal yang tidak dapat dilepaskan di dalam menjaga serta merawat agar tanaman dapat tumbuh dengan subur. Kebutuhan air yang cukup merupakan salah satu hal yang sangat penting. Jika hal ini telah salah digunakan akan berdampak fatal bagi perkembangan tanaman itu sendiri.

Melihat dari beberapa permasalahan tersebut, dibutuhkan perencanaan yang sangat komplek guna mempermudah di dalam membantu kehidupan manusia. Apalagi jika sistem tersebut bergerak dengan suatu kendali yang terpadu, maka hal ini akan membawa dampak kepada manusia untuk bisa memikirkan dan membuat suatu bentuk kontrol yang sekiranya akan dapat

TELKA, Vol.2, No.2, November 2016, pp. 138 149

ISSN (e): 2540-9123

ISSN (p): 2502-1982 
membantu dengan efisien. Salah satu solusi untuk mengatasi hal tersebut yaitu dengan mengembangkan sebuah Sistem pengontrol greenhouse yang dapat diatur melalui web kemudian hasil pemantauan diinteraksikan ke jejaring sosial facebook.

\section{Dasar Teori}

\subsection{Cara Kerja Greenhouse}

Rumah kaca atau green house pada prinsipnya adalah sebuah bangunan yang terdiri atau terbuat dari bahan kaca atau plastik yang sangat tebal dan menutup diseluruh pemukaan bangunan, baik atap maupun dindingnya. Didalamnya dilengkapi juga dengan peralatan pengatur temperatur dan kelembaban udara serta distribusi air maupun pupuk.

Apabila intensitas cahaya matahari pada rumah kaca terlalu besar sehingga dapat meningkatkan temperatur dalam rumah kaca, maka atap pada rumah kaca akan diganti dengan warna yang lebih gelap dengan digerakkan oleh motor stepper. Sedangkan bila intensitas cahaya matahari mengalami penurunan, maka atap pada rumah kaca akan diganti dengan warna yang lebih terang (transparan) juga digerakkan oleh motor stepper. Apabila cahaya matahari tidak tersedia akibat faktor cahaya, maka perangkat pengendalian intensitas cahaya tersebut akan menghidupkan lampu secara otomatis dan akan mematikan lampu apabila cahaya matahari telah kembali seperti sedia kala. Jika kelembaban rendah, maka dilakukan penyemprotan air dan jika suhu rendah dapat diatur dengan memasang lampu.

\subsection{Web Server}

Web service adalah suatu sistem perangkat lunak yang dirancang untuk mendukung interoperabilitas dan interaksi antar sistem pada suatu jaringan. Web service digunakan sebagai suatu fasilitas yang disediakan oleh suatu situs web untuk menyediakan layanan (dalam bentuk informasi) kepada sistem lain, sehingga sistem lain dapat berinteraksi dengan sistem tersebut melalui layanan-layanan yang disediakan oleh suatu sistem yang menyediakan web service.

\subsection{PHP sebagai Bahasa Scripting dalam Web}

PHP merupakan sebuah bahasa scripting yang menyatu dengan tag-tag HTML, dieksekusi di server dan digunakan untuk membuat halaman web yang dinamis. Diagram alur web dinamis dengan menggunakan Gambar 1 merupakan prinsip kerja PHP dalam web.

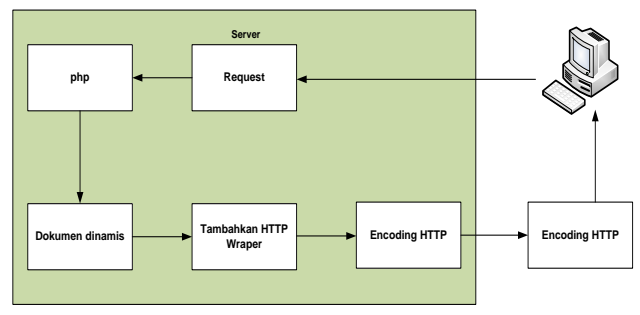

Gambar. 1 prinsip kerja PHP dalam web

\subsection{API Facebook}

API singkatan dari Application Programming Interface. Facebook API merupakan antar muka pemrograman web services (web services programming interface) untuk mengakses layanan utama Facebook (login, redirect, update view). API ini berbasis arsitektur REST (Representational State Transfer).

\subsection{Mikrokontroler Atmega32}

Mikrokontroler adalah suatu sistem komputer yang diaplikasikan dalam satu chip. Mikrokontroler yang digunakan pada sistem ini merupakan produk dari atmel dengan seri avr atmega32. Mikrokontroler AVR Atmega32 memiliki fitur yang cukup lengkap. Mikrokontroler AVR Atmega32 telah dilengkapi dengan ADC internal, EEPROM internal, Timer/Counter, jalur 
komunikasi $\mathrm{I}^{2} \mathrm{C}$ dan serial komunikasi UART. Sehingga dengan fasilitas yang lengkap ini memungkinkan untuk menggunakan mikrokontroler keluarga AVR dengan lebih mudah dan efisien.

\subsection{Sensor}

Secara umum sensor didefenisikan sebagai alat yang mampu menangkap fenomena fisika atau kimia kemudian mengubahnya menjadi sinyal electrik baik arus listrik ataupun tegangan. Sensor yang digunakan dalam pengontrol greenhouse ini adalah sensor DT-Sense suhu dan kelembaban berbasis SHT10, sensor cahaya DT-Sense dan sensor kelembaban tanah YL-69.

\subsection{Aktuator}

Aktuator adalah sebuah peralatan mekanis untuk menggerakkan atau mengontrol sebuah mekanisme atau sistem. Aktuator yang digunakan adalah modul relay 2.0 denga 8 buah relay dengan driver IC ULN2083 yang merupakan IC yang didalamnya terdapat 8 buah susunan transistor darlington. Digunakan untuk menggerakkan valve, kipas dan lampu.

\subsection{Komunikasi RS 485}

Komunikasi dengan RS-485 merupakan salah satu solusi yang dapat digunakan untuk pengiriman data jarak jauh dan memiliki kecepatan transfer lebih tinggi dari pada komunikasi RS-232.

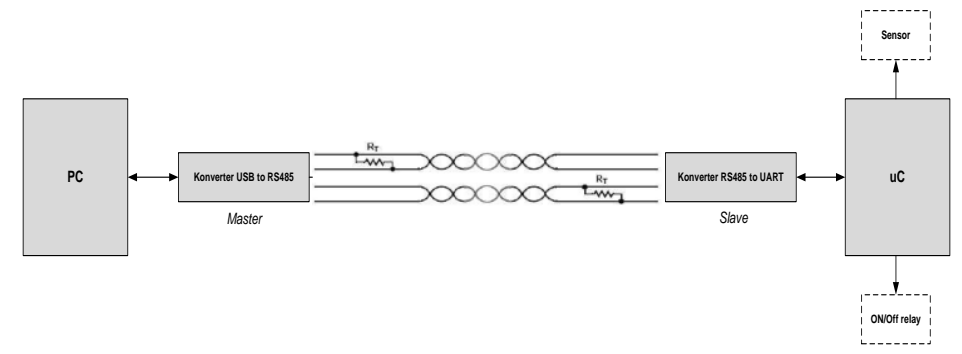

Gambar. 2 Model Komunikasi RS-485

\section{Perancangan Sistem}

\subsection{Diagram Sistem}

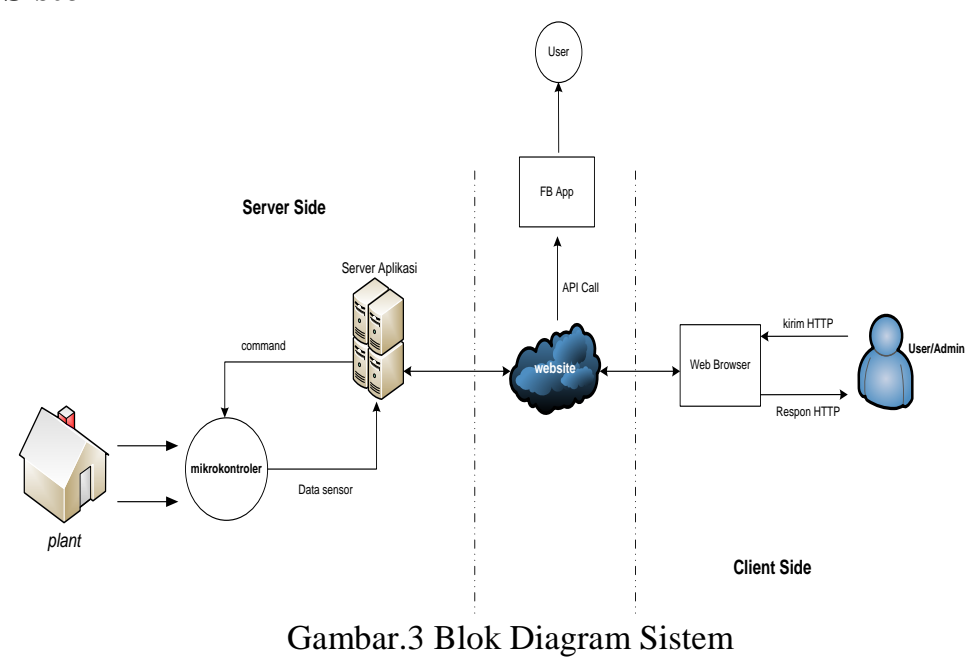

Secara umum proses dalam sistem pada Gambar 3 yang telah dirancang terdiri atas dua bagian utama, yaitu proses yang dilakukan pada sisi client dan proses yang dilakukan pada sisi server. Untuk menghubungkan proses pada client dengan server menggunakan media internet melalui website. 
Proses kerja sistem diawali dari masing-masing sensor yang terpasang terdiri dari modul sensor suhu dan kelembaban udara serta sensor kelembaban tanah (soil moistur) akan membaca setiap perubahan kondisi lingkungan tanaman (plant) sesuai dengan fungsinya. Setiap sensor terhubung ke setiap pin mikrokontroler sesuai dengan jalur data yang digunakan. Setelah dari blog mikrokontroler, data sensor yang terbaca akan dikirim ke komputer melalui komunikasi serial. Selain dikirimkan ke komputer, data sensor juga ditampilkan di LCD.

Setiap data sensor yang terkirim ke server akan disimpan didalam database mysql yang selanjutnya akan diolah dalam web aplikasi dalam bentuk grafik. Data hasil olahan tadi juga dapat secara otomatis terupdate sesuai pengaturan waktu yang telah disediakan melalui jaringan LAN yang terhubung ke internet di halaman facebook sebagai penyebaran informasi kondisi greenhouse. Misalnya apabila tanaman telah disiram penuh, maka status akun tanaman di facebook akan tertulis "Tanaman telah disiram". Apabila kelembaban tanah semakin berkurang, maka penurunan persentase kelembabannya akan muncul di status facebook. Apabila tanah kering, maka status di facebook akan tertulis "Butuh penyiraman". Serta segala aktifitas yang dilakukan aktuator juga dipantau melalui facebook.

Selain memantau kondisi tanaman (plant), sistem ini juga dirancang untuk dapat melakukan penyiraman tanaman secara jarak jauh (remote) melalui jaringan internet sesuai kebutuhan secara manual ataupun secara otomatis yang dijadwalkan. Untuk dapat melakukan perintah penyiraman, hanya user yang memiliki otoritas hak akses yang dapat melakukan aksi penyiraman. Apabila administrator tidak mengaktifkan komunikasi serial dari aplikasi web atau server sedang tidak aktif maka mikrokontroler akan tetap dapat menyiram berdasarkan nilai sensor yang telah ditetapkan.

\subsection{Analisis Kebutuhan Sistem}

Kebutuhan sistem dalam penelitian ini adalah sebagai berikut.

- Pusat pengontrol sistem sepenuhnya berada pada aplikasi komputer;

- Komunikasi data server (komputer) ke client (mikrokontroler) dengan komunikasi serial;

- Waktu penyiraman atau pemberian nutrisi dapat diatur melalui aplikasi web sesuai kebutuhan;

- Sistem dalam memantau dan share informasi ke facebook dapat diatur waktunya sesuai kebutuhan;

- Sistem dirancang minimal untuk dapat melakukan fungsi siraman dengan 3 (tiga) valve elektric;

- Setiap data sensor tidak langsung dikirim ke komputer akan tetapi terlebih dahulu disimpan dalam buffer;

- Komunikasi data akan dapat berfungsi, jika komunikasi data serial diaktifkan terlebih dahulu melalui aplikasi web;

- Apabila mengalami listrik mati atau server aplikasi tidak aktif, maka sistem harus dapat mengaktifkan aktuator dan harus dapat mengatur kebutuhan cahaya tanaman berdasarkan hasil pembacaan nilai sensor;

- Perangkat untuk pengontrolan menggunakan $P C$ ataupun gadget mobile;

- Aplikasi dibuat berbasis web;

- Aplikasi dapat diakses melalui intranet ataupun internet. 


\subsection{Perangkat Lunak Mikrokontroler}

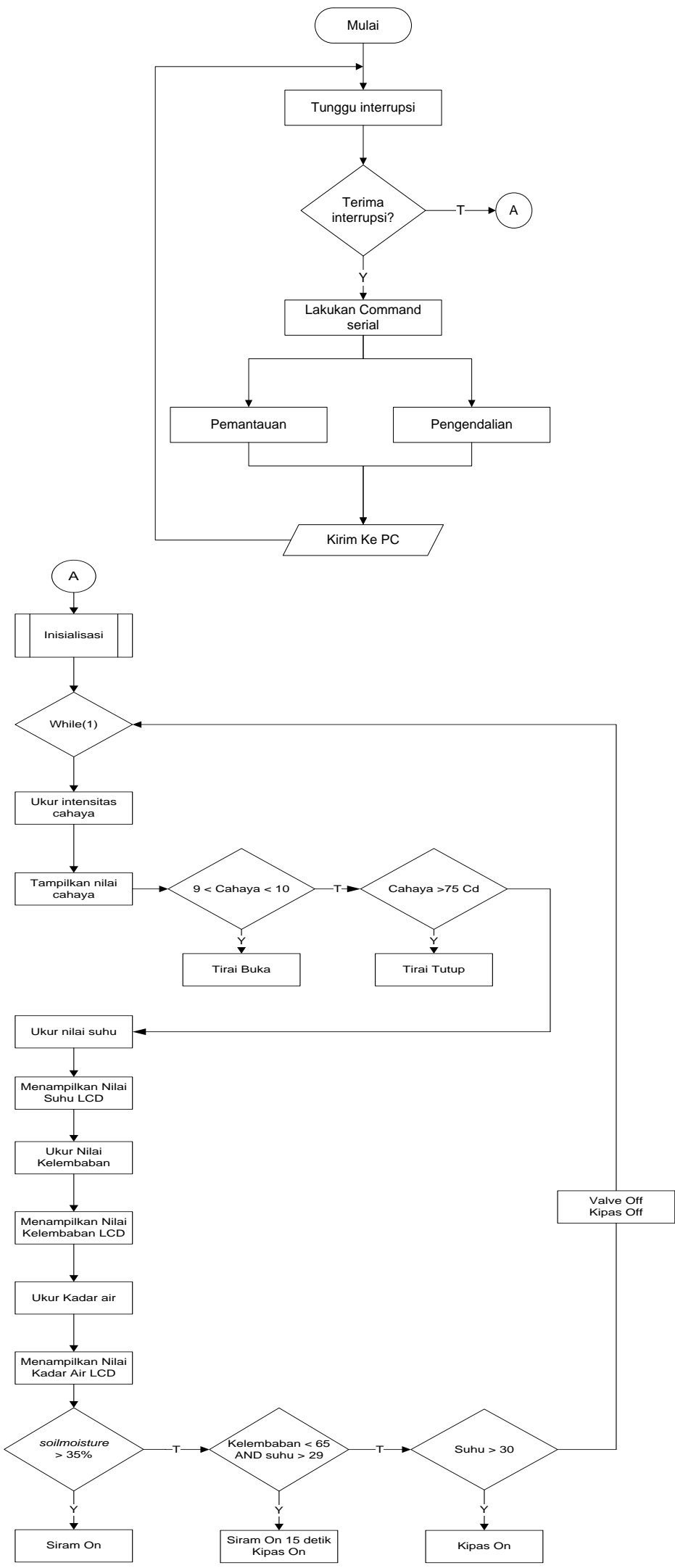

Gambar.4 Diagram Alir Program Mikrokontroler 


\subsection{Proses Transmisi Data dari Mikrokontroler ke PC Server}

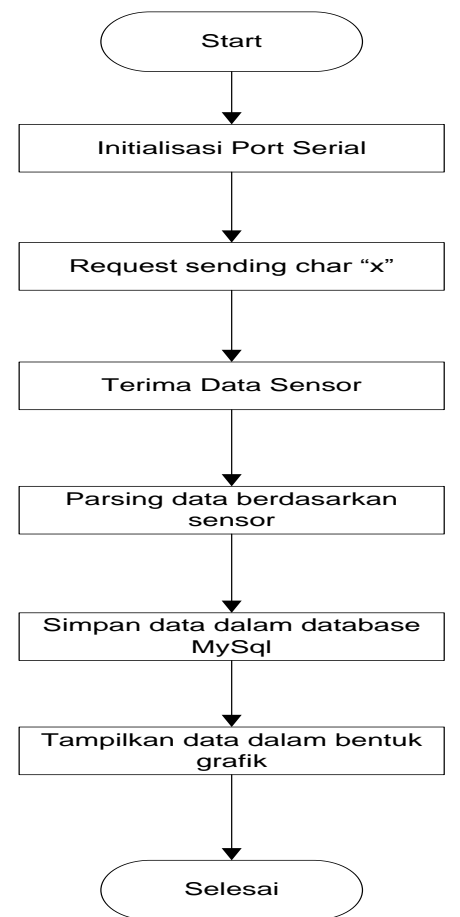

Gambar. 5 Proses Komunikasi serial Mikrokontroler ke Komputer

Proses awal yaitu inisialisasi port serial dengan mengatur preferensi komunikasi (baud rate, data bit, stop bit, paritas).Selanjutnya Proses read/write dari port serial diawali dengan aplikasi PHP serial melakukan request dengan mengirimkan sebuah karakter " $x$ " yang sebelumnya sudah ditentukan untuk pengambilan data sensor ke port serial. Jika karakter ini diterima, maka respon akan diterima kembali. Setelah menerima data, langkah selanjutnya adalah data sensor yang diterima akan di parsing terlebih dahulu berdasarkan data sensor yang diterima. Kemudian data hasil parsing akan dimasukkan ke kolom database yang telah di tentukan.

\subsection{Perancangan Kendali Manual}

Pada perancanganya proses kendali ini dibuatkan sebuah mockup web interface seperti Gambar.6 yang terdiri dari beberapa tombol on/off untuk menghidupkan dan mematikan aktuator untuk kendali greenhouse. Dimana setiap tombol dikodekan untuk melakukan aksi kendali terhadap aktuator.

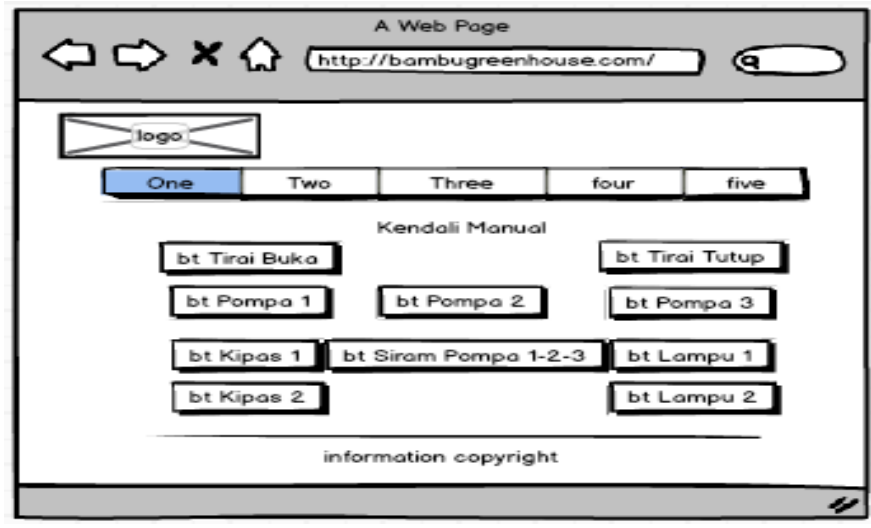

Gambar. 6 Mockup User Interface Kendali Manual 
Proses kendali di gambarkan ke dalam bentuk Data Flow Diagram (DFD) seperti Gambar.7 berikut.

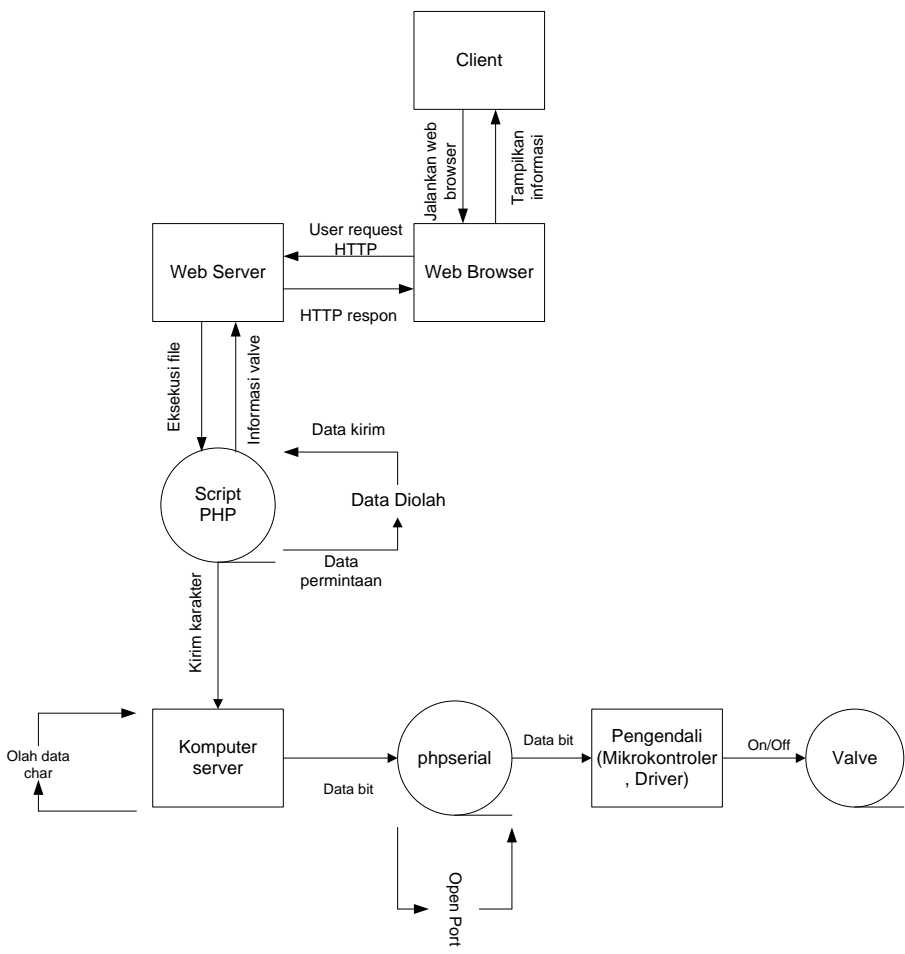

Gambar.7 DFD proses kendali manual

Sistem kendali jarak jauh yang dirancang ini bergantung pada permintaan user/client yang akan mengakses website melalui web browser. Menekan salah satu tombol (button) yang ada pada halaman web tersebut mengakibatkan aplikasi web dengan script PHP akan meresponnya. Kemudian, akan mengirimkanya ke PC server. PC server akan mengolah dan mengkonversi data char ke bentuk data bit yang selanjutnya dikirim ke mikrokontroler dengan mengeksekusi PHP serial class untuk mematikan ataupun menghidupkan valve.

\subsection{Perancangan Aplikasi Penjadwalan}

Rancangan Aplikasi penjadwalan disesuaikan dengan format penulisan dan pengaturan waktu dalam crontab seperti contoh berikut ini.

$$
\text { “*****/root/script.sh “ }
$$

Untuk mempermudah proses perancangan fungsi - fungsi yang akan digunakan dalam software dibuatlah diagram blog perancangan seperti pada Gambar. 8 dalam bentuk deployment diagram berikut.

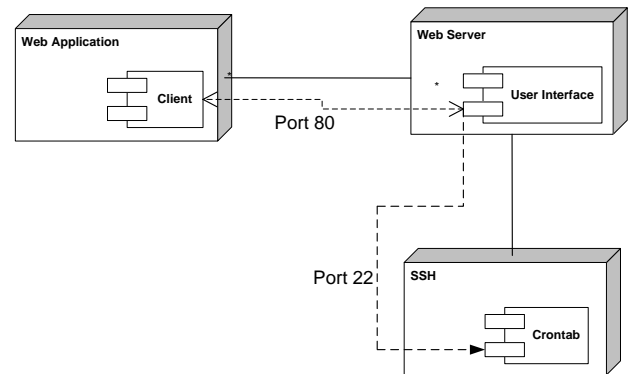

Gambar.8 Deployment Diagram Perancangan Aplikasi Penjadwalan 


\subsection{Proses Interaksi Aplikasi ke Facebook}

Facebook digunakan sebagai media penyebaran informasi dan pemantauan kondisi aktifitas greenhouse. Proses dilakukan dengan meng-interaksikan aplikasi dengan facebook. Dalam interaksinya dibutuhkan beberapa hal salah satunya komputer server harus memiliki DNS (Domain Name System) sendiri dengan cara menginstal aplikasi BIND dan kemudian dilakukan konfiguasi pada BIND tersebut.

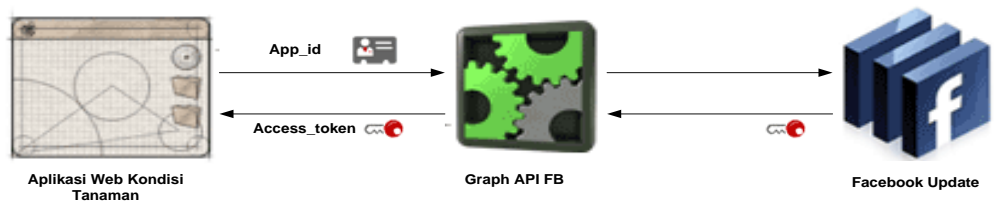

Gambar. 9 Diagram Blok Interaksi Aplikasi ke Facebook

Proses update status diawali dengan melakukan login ke aplikasi facebook. Aplikasi kemudian melakukan invoke HTTP POST kepada endpoint dari facebook graph API. Selanjutnya facebook melakukan crawling terhadap objek dari halaman aplikasi, membaca metadata, dan menyambungkan dengan objek - objek terkait yang telah diberi autentifikasi.

Akses permission dibutuhkan untuk mendapatkan hak akses pada scope yang direquest dan ini merupakan penanda bahwa telah diberikan hak akses penuh ke facebook. Kemudian data dari database yang telah diolah akan ditampilkan terupdate ke facebook secara manual sesuai eksekusi tombol update ataupun secara otomatis yang telah dijadwalkan.

\section{Hasil dan Pembahasan}

\subsection{Pengujian Transmisi Data dari Mikrokontroler ke PC Server}

Pengujian dilakukan dengan menjalankan software interface yaitu file data.php yang berisi instruksi pengambilan data sensor di crontab yang telah diatur setiap 5 menit sekali. Jika eksekusi berhasil, maka data akan tersimpan dalam database seprti Gambar 10 berikut.

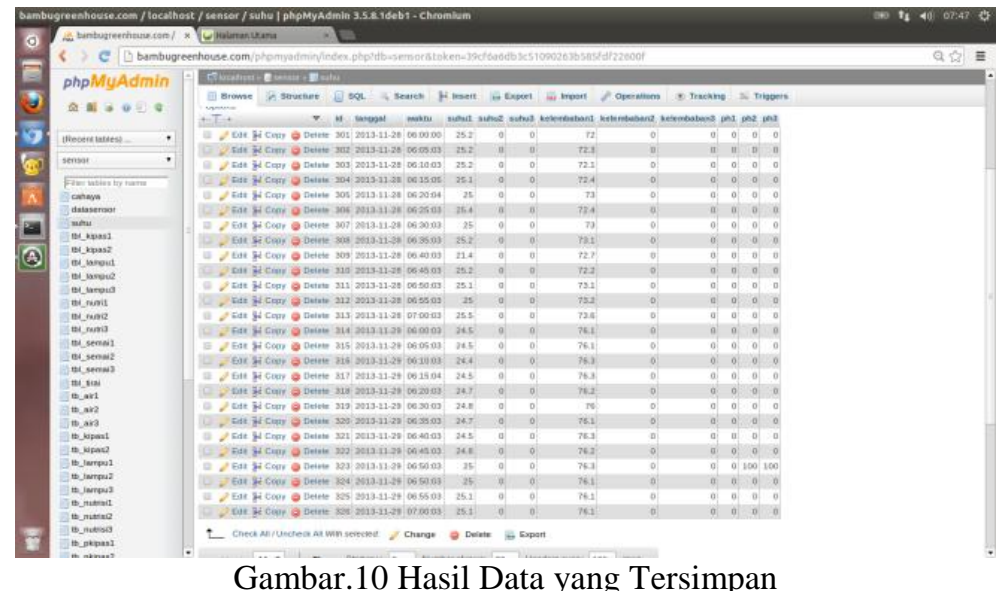

Kemudian data yang diterima akan ditampilkan dalam bentuk grafik seperti berikut. 


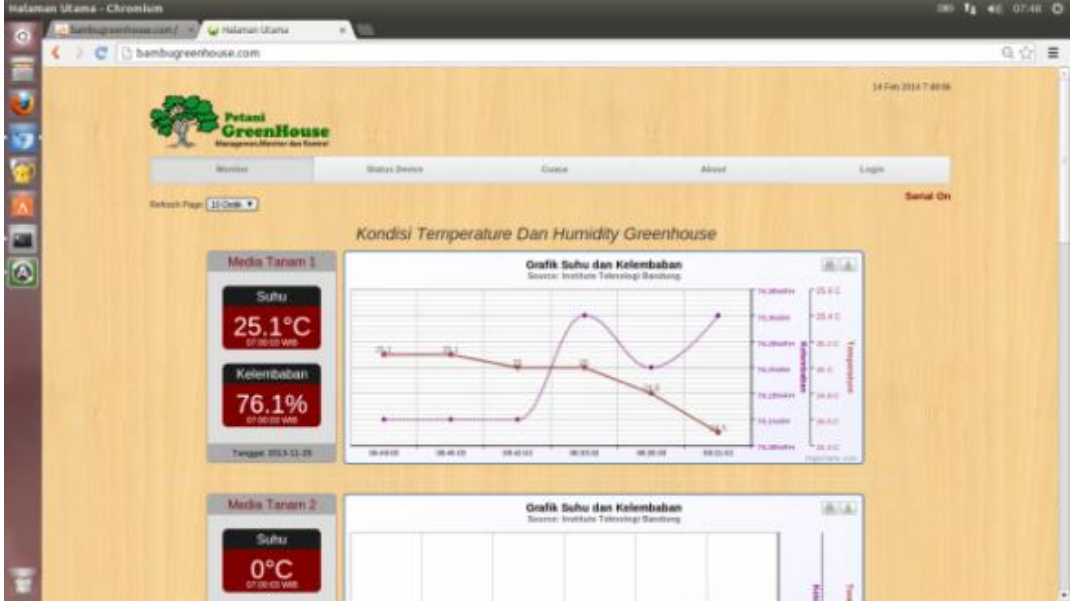

Gambar.11 Hasil Grafik Transmisi Data

\subsection{Pengujian Aplikasi Kendali Manual}

Langkah pengujian yaitu:

1. Client melakukan permintaan halaman aplikasi kendali manual dengan ketik http://bambugreenhoouse.com/log/kontrol.php.

2. Serve akan menampilkan halaman panel kontrol manual.

3. Client melakukan akses dengan memberikan masukkan berupa penekanan tomboltombol kontrol panel. Setiap tombol yang di tekan akan mengeksekusi PHPserialport.php untuk membuka port serial dan mengirimkan kode ke mikrokontroler untuk menghidupkan aktuator dan memberikan informasi berupa aktuator telah aktif.

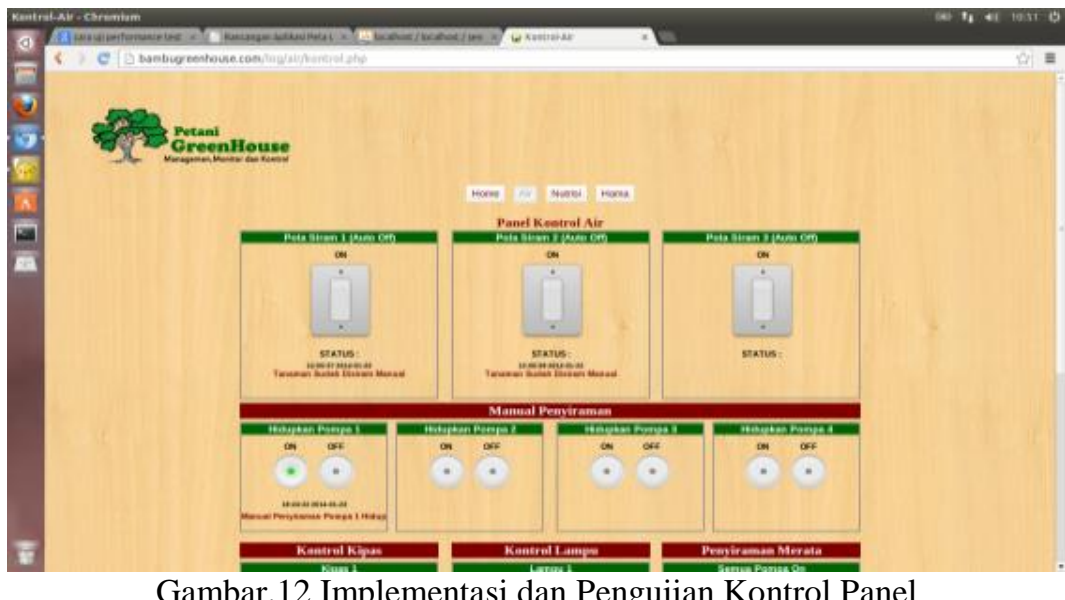

Tabel.1 Hasil Pengujian Kontrol Real Time

\begin{tabular}{cccc}
\hline No & Tombol Eksekusi & Valve & Kondisi \\
\hline $\mathbf{1}$ & Siram 1 & Kran 1 & Berhasil \\
$\mathbf{2}$ & Siram 2 & Kran 2 & Berhasil \\
$\mathbf{3}$ & Siram 3 & Kran 3 & Berhasil \\
\hline
\end{tabular}

\subsection{Pengujian Aplikasi Penjadwalan}

Langkah pengujian yaitu:

1. Client melakukan permintaan halaman aplikasi penjadwalan dengan ketik http://bambugreenhoouse.com/log/penjadwalan.php.

2. Server akan menampilkan halaman penjadwalan Gambar.13

3. Client akan melakukan aksi dengan melakukan setting waktu dan aktifitas eksekusi yang dikehendaki pada kolom yang tersedia. Kemudian klik tombol simpan. 
4. Jika berhasil tersimpan, maka pada tabel crontab disistem operasi linux akan tersimpan hasil setting waktu dari aplikasi web. (Gambar.14).

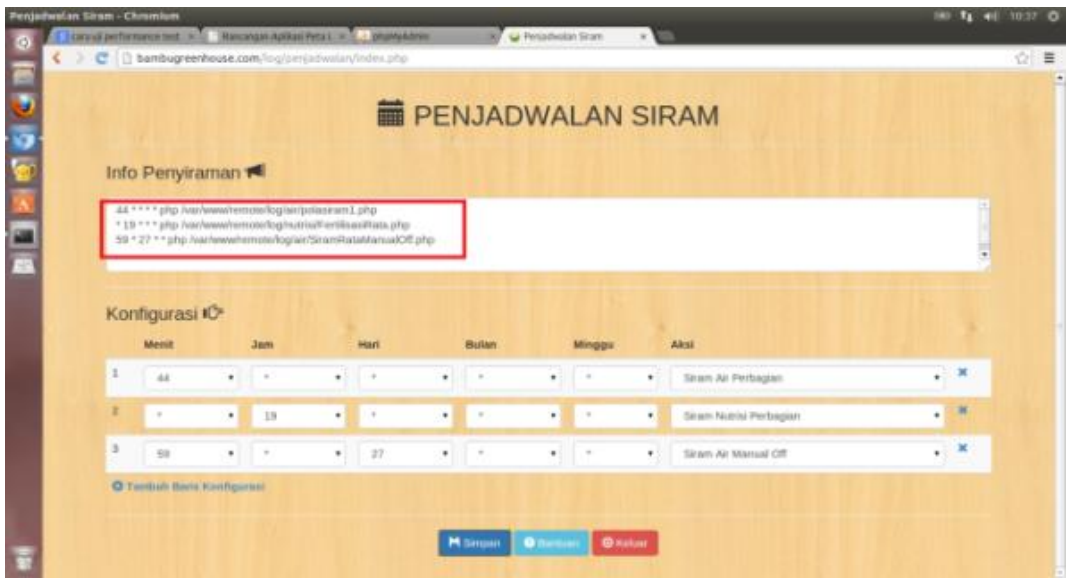

Gambar.13 Halaman Penjadwalan

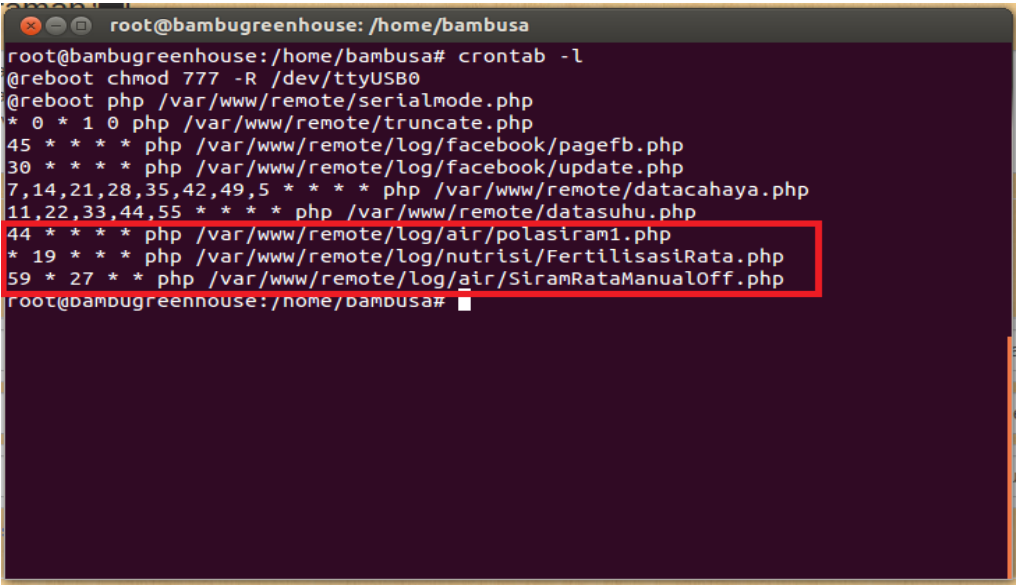

Gambar.14 Hasil Setting Penjadwalan dari Aplikasi Web

Tabel.2 Hasil Pengujian Setting Penjadwalan dan Kontrol Terjadwal

\begin{tabular}{clcc}
\hline No & \multicolumn{1}{c}{ Halaman Crontab } & Valve & Kondisi \\
\hline $\mathbf{1}$ & $\begin{array}{l}\text { Eks. }{ }^{*} \text { Kontrol valve 1 tersimpan } \\
\text { di crontab }\end{array}$ & Kran 1 & Berhasil \\
$\mathbf{2}$ & $\begin{array}{l}\text { Eks. }{ }^{*} \text { Kontrol valve 2 tersimpan } \\
\text { di crontab }\end{array}$ & Kran 2 & Berhasil \\
$\mathbf{3}$ & $\begin{array}{l}\text { Eks. }{ }^{*} \text { Kontrol valve 3 tersimpan } \\
\text { di crontab }\end{array}$ & Kran 3 & Berhasil \\
\hline
\end{tabular}

Setiap perintah eksekusi yang disetting dan tersimpan didalam tabel crontab berhasil dieksekusi untuk melakukan kontrolpada aktuator valve.

\subsection{Pengujian Post Data ke Facebook}

Pengujian dilakukan dengan menjalankan file program autoupdate.php yang berisi instruksi data kondisi greenhouse di crontab. Crontab diatur melalui aplikasi penjadwalan setiap 60 menit untuk dapat melakukan update. Pengujian dilakukan sampling sebanyak 10 kali pengujian. Hasil pengujian. 
Tabel.3 Hasil Monitoring Ke Facebook

\begin{tabular}{cc}
\hline am-ke & Status \\
\hline $\mathbf{1}$ & Berhasil \\
$\mathbf{2}$ & Berhasil \\
$\mathbf{3}$ & Berhasil \\
$\mathbf{4}$ & Berhasil \\
$\mathbf{5}$ & Berhasil \\
$\mathbf{6}$ & Berhasil \\
$\mathbf{7}$ & Berhasil \\
$\mathbf{8}$ & Berhasil \\
$\mathbf{9}$ & Berhasil \\
$\mathbf{1 0}$ & Berhasil \\
\hline
\end{tabular}

Hasil Capture pengujian post data otomatis ke facebook.

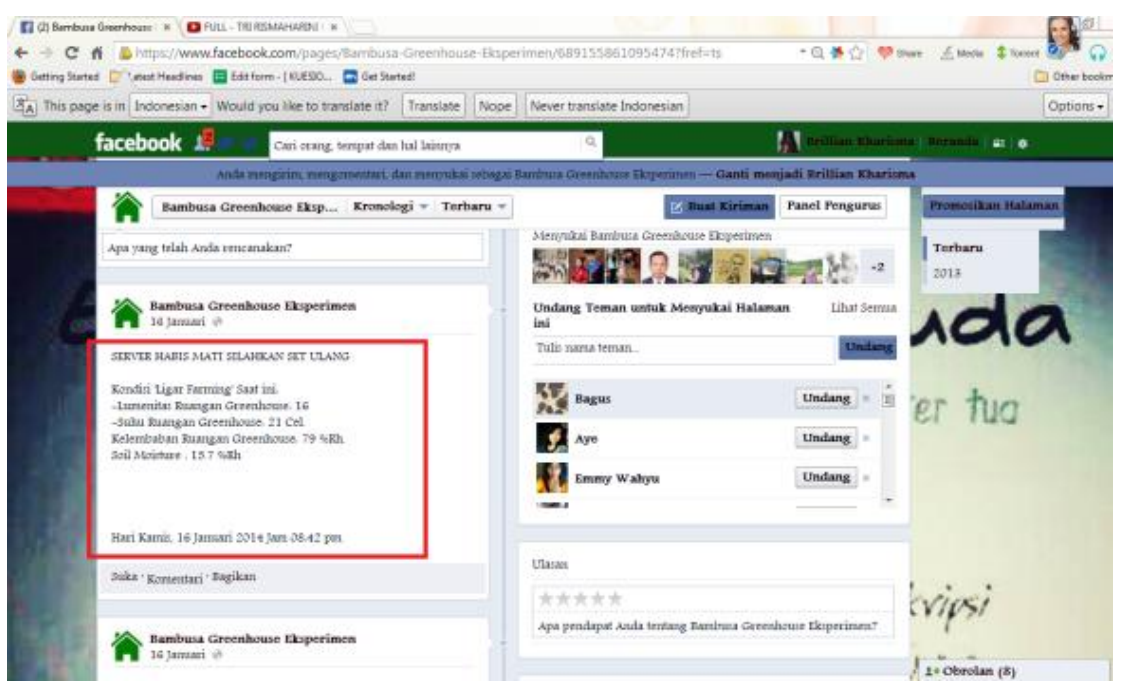

Gambar.15 Hasil Post Facebook

Hasil monitoring kondisi plant ke facebook menunjukkan bahwa sistem $100 \%$ berhasil melakukan update. Keberhasilan di post dipengaruhi oleh koneksi jaringan ke internet.

\section{Kesimpulan}

Sistem yang bangun merupakan sebuah sistem pengontrol greenhouse melalui web yang dinteraksikan dengan media sosial facebook. Dari hasil pengujian dapat disimpulkan sebagai berikut:

1. Aplikasi yang dibuat dalam proses transmisi data sensor dapat berjalan dengan baik.

2. Aplikasi kendali manual maupun yang dijadwalkan, dapat mengontrol dan memonitor aktuator berupa valve melalui jaringan internet.

3. Hasil post data kondisi greenhouse ke facebook telah $100 \%$ berhasil. Selama koneksi jaringan tidak mengalami gangguan.

\section{Daftar Pustaka}

[1] Alexander Rahardjo,dkk , Rancang Bangun Aplikasi Pengaturan Dan Pengendalian Suhu Ruang Server Berbasis Web Service Dan Sms Gateway, http://digilib.its.ac.id/public/ITS-Undergraduate-15329-Paper-pdf.pdf download 1 Januari 2015, 06.30 WIB.

[2] Doss, George M .2000. Tip Sistem Operasi Red-Hat, Jakarta : PT Elex Media Komputindo. 
[3] Jason, W. Gilmore. 2010. Beginning PHP and MySQL From Novice to Professional 4th Edition. Apress.

[4] Richard, Wagner .2008. Building Facebook Applications for Dummies, Willey Publishing Inc.

[5] Samson, Technocal Informationx, Serial Data Transmission, http://www.samson.de/pdf_en/1153en.pdf, download 4 Februari 2015, 17.00 WIB.

[6] http://devitasari74.wordpress.com/2013/01/08/peluang-usaha-pertanian-dengangreenhouse/, diakses 3 Januari 2015, 17.00 WIB. 